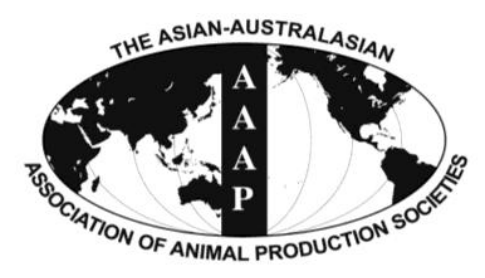

Asian Australas. J. Anim. Sci.

Vol. 26, No. 5 : 691-699 May 2013

http://dx.doi.org/10.5713/ajas.2012.12429

www.ajas.info

pISSN 101 1-2367 elSSN 1976-5517

\title{
The Metabolizable Energy Value, Standardized lleal Digestibility of Amino Acids in Soybean Meal, Soy Protein Concentrate and Fermented Soybean Meal, and the Application of These Products in Early-weaned Piglets
}

\author{
H. Y. Zhang, J. Q. Yi, X. S. Piao*, P. F. Li, Z. K. Zeng, D. Wang, L. Liu ${ }^{1}$, G. Q. Wang and X. Han \\ Ministry of Agriculture Feed Industry Centre, State Key Laboratory of Animal Nutrition, \\ China Agricultural University, Beijing 100193, China
}

\begin{abstract}
Three experiments were conducted to evaluate the metabolizable energy (ME) value, standardized ileal digestibility (SID) of amino acids (AA) of soybean meal (SBM), soy protein concentrate (SPC) and fermented soybean meal (FSBM), and the application of these products in early-weaned piglets. In Exp. 1, four barrows with initial body weight (BW) of $14.2 \pm 1.4 \mathrm{~kg}$ were used in a $4 \times 4$ Latin square design. The diet 1 contained corn as the only energy source. The other three diets replaced $25 \%$ of corn in diet 1 with one of the three soybean products, and the digestable energy (DE) and ME contents were determined by difference. In Exp. 2, four barrows (initial BW of $18.2 \pm 1.5 \mathrm{~kg}$ ) were fitted with ileal T-cannulas and allotted to a $4 \times 4$ Latin square design. Three cornstarch-based diets were formulated using each of the soybean products as the sole source of AA. A nitrogen-free diet was also formulated to measure endogenous losses of AA. In Exp. 3, ninety six piglets (initial BW of $5.6 \pm 0.9 \mathrm{~kg}$ ) weaned at $21 \pm 2 \mathrm{~d}$ were blocked by weight and assigned to one of three treatments for a 21-d growth performance study. The control diet was based on corn and SBM, the two treatments' diets contained either 10\% SPC or FSBM and were formulated to same SID lysine to ME ratio of 3.6 g/Mcal. The results showed that the ME content of SPC was greater than SBM $(\mathrm{p}<0.05)$. The SID of most AA in SPC was greater than the SID of AA in SBM $(\mathrm{p}<0.05)$. For the essential AA, the SID of histidine, isoleucine, leucine, lysine and threonine in FSBM were greater than in SBM $(\mathrm{p}<0.05)$. Even though they were fed same SID lysine to ME ratio of 3.6 g/Mcal diets, pigs fed SPC and FSBM diets had greater weight gain, G:F $(\mathrm{p}<0.05)$ and better fecal score $(\mathrm{p}<0.05)$ than pigs fed SBM diet. In conclusion, SPC showed a higher ME content and SID of AA than the SBM. SID of some essential AA in FSBM was higher than SBM and was similar with SPC. But the lower antigenic proteins and anti-nutritional factors content in SPC and FSBM may be the main factors affecting the performance of early-weaned piglets rather than the increased ME content and SID of AA. (Key Words: Metabolizable Energy, Standardized Ileal Digestibility, Soybean Meal, Soy Protein Concentrate, Fermented Soybean Meal, Early-weaned Piglets)
\end{abstract}

\section{INTRODUCTION}

SBM is one of the most commonly used protein sources in the animal feed industry owing to its balance of AA and high nutritional value (Cromwell, 2000). However, the presence of antigenic proteins such as glycinin, $\beta$-conglycinin and anti-nutritional factors such as TI and lectins in soybean could cause hypersensitivity for newly weaned piglets which may decrease nutrient availability and therefore restrict its' inclusion in diets fed to weaning pigs

\footnotetext{
* Corresponding Author: X. S. Piao. Tel: +86-10-62733588, Fax: +86-10-62733688, E-mail: piaoxsh@mafic.ac.cn

${ }^{1}$ Zhongsheng Group, Tianjin 300380, China.

Submitted Aug. 9, 2012; Accepted Nov. 1, 2012; Revised Nov. 6, 2012
}

(Li et al., 1990; Csaky and Fekete, 2004; Hao et al., 2010).

Sohn et al. (1994a) showed that protein sources from further processing of soybeans could improve the growth performance of early-weaned pigs. SPC and FSBM are two kinds of different processing products. SPC is a high quality protein source for use in diets fed to piglets (Sissons and Smith, 1976; Kilshaw and Sissons, 1979). It contains lower amounts of immunologically active glycinin, $\beta$-conglycinin and TI than SBM, also, some soluble carbohydrates, primarily sucrose, raffinose, and stachyose in it have been removed (Hamerstrand et al., 1981; Lenehan et al., 2007). FSBM has become an accepted protein product in diets fed to weaning piglets in recent years (Kim et al., 2005; Cho et al. 2007; Jones et al., 2010). Microbial fermentation could 
eliminate many of the anti-nutritional factors and improves the nutritional value of SBM (Hong et al., 2004; Feng et al., 2007). During fermentation, the large protein, lipid and carbohydrate molecules are broken down to smaller molecules such as peptides, AA, fatty acids and sugars (Kwon et al., 2010).

However, in general, the addition amount of SPC and FSBM is less than $10 \%$ in pigs' diets; the relatively small inclusion of them may only increase the total nutrients digestibility slightly in diet. Therefore, we hypothesize the lower antigenic proteins and anti-nutritional factors in SPC and FSBM may be the main effective factors to improve performance of early-weaned piglets. The objective of the current experiment was to determine the ME content as well as the SID of AA in SBM, SPC and FSBM, based on the $\mathrm{ME}$ and SID of AA values, to evaluate the effects of same SID lysine to ME ratio diets containing the three soybean products on performance and fecal score of early-weaned piglets.

\section{MATERIALS AND METHODS}

\section{General}

The experimental protocols used in these experiments were approved by the Institutional Animal Care and Use Committee of China Agricultural University (Beijing, China). SBM (Commercially processed), SPC (Gushen Biological Technology Group, Qingdao, China) and FSBM (CJ Corporation, Seoul, Korea) were used for this study.

\section{Animals and experimental design}

Experiment 1: Four barrows (Duroc $\times$ Landrace $\times$ Large White) with initial $\mathrm{BW}$ of $14.2 \pm 1.4 \mathrm{~kg}$ were used to determine the DE and ME contents of the three soybean products. Pigs were allotted to four experimental treatments in a $4 \times 4$ Latin square design. Four diets were formulated to determine the DE and ME contents of soybean products (Table 2). In the first diet, corn was the only energy source (96.45\% corn and $3.55 \%$ minerals and vitamins) and this diet was used to determine the DE and ME content of corn. In the remaining three diets, $25 \%$ of one of the three soybean products was substituted at the expense of corn and the energy values of the soybean products were determined by difference on the assumption that their contributions were additive (Adeola and Bajjalieh, 1997; Woodworth et al., 2001).

Pigs were housed in stainless-steel metabolism cages that allowed separate collection of feces and urine. The cages were located in an environmentally controlled room with a temperature between 24 and $26^{\circ} \mathrm{C}$. Each feeding period consisted of $5 \mathrm{~d}$ for diet adaptation, followed by $5 \mathrm{~d}$ of total collection of feces and urine. Pigs had free access to water and the quantity of feed provided per pig daily was calculated as 3 times the estimated requirement for maintenance energy for the smallest pig in each replicate and divided into 2 equal meals. In the morning meal on $\mathrm{d} 6$ and 9, $1 \mathrm{~g}$ of chromic oxide was mixed into the meal and used as a fecal marker. Feces collection from each pig was initiated with the first appearance of the marker in the feces after d 6 and collection ceased when the marker first appeared in the feces after d 9 (Petersen and Stein, 2006). Fecal samples were collected and immediately stored at $-20^{\circ} \mathrm{C}$. The feces for an individual pig from the total collections were mixed together after thawing. After mixing, a representative sub-sample was obtained from each pig's fecal material for analysis. Urine was collected in plastic buckets containing $50 \mathrm{ml}$ of $6 \mathrm{~N} \mathrm{HCl}$ as a preservative. Buckets were emptied twice daily and $20 \%$ of the daily urine collection was stored at $-20^{\circ} \mathrm{C}$. At the end of the experiment, urine samples were thawed and sub-samples were collected for analysis (Goebel and Stein, 2011).

Experiment 2: Four barrows (Duroc $\times$ Landrace $\times$ Large White) with a BW of $18.2 \pm 1.5 \mathrm{~kg}$ were surgically fitted with a T-cannula at the distal ileum according to the method described by Stein et al. (1998). After surgery, pigs were transferred to adjustable metabolic crates $(1.8 \times 0.8 \mathrm{~m})$ in a temperature-controlled room $\left(24^{\circ} \mathrm{C}\right)$. A standard diet and water were provided ad libitum during the 10-d recovery period before starting the experiment. Then pigs were randomly assigned to a $4 \times 4$ Latin square design. The cornstarch-based diets (Table 3 ) were formulated to contain each product as the only AA source. Diet 1 was a nitrogenfree diet which was used to determine endogenous AA losses. The three experimental diets were formulated with regard to previous research which observed that inclusion of increased amounts of SBM in diets fed to weaning pigs may cause allergic reactions, which potentially could influence the results for the diet containing SBM (Cervantes-Pahm and Stein, 2010). In the present study, diets 2, 3 and 4 were formulated to contain different levels of each soybean product to provide the same amount of CP (12.88\%) in each diet. All diets contained $0.30 \%$ chromic oxide as an indigestible marker.

Each feeding period consisted of a 5-d adaptation period followed by $2 \mathrm{~d}$ for collection of ileal digesta. Pigs were fed the diets at three times their maintenance energy requirement, based on their $\mathrm{BW}$ at the beginning of each period. Feed allowance was divided into two equal meals and fed at 0800 and 1630 each day. Ileal digesta were collected continuously for $12 \mathrm{~h}$ from 0800 to $2000 \mathrm{~h}$ on $\mathrm{d} 6$ and 7 (Stein et al., 1998). A plastic bag was attached to the cannula using a cable tie to collect the digesta flowing into the bag. Bags were changed every $20 \mathrm{~min}$. Ileal digesta were stored on ice during the 12 -h collection period. After each day's collection, digesta were stored at $-20^{\circ} \mathrm{C}$ to prevent bacterial degradation of the amino acids in the 
digesta. The two samples obtained from each pig were homogenized after the 2-d collection. Digesta were lyophilized and a sub-sample was collected for analysis.

Experiment 3: A total of 96 crossbred pigs (Duroc $\times$ Landrace $\times$ Large White; initial BW of $5.6 \pm 0.9 \mathrm{~kg}$ ) weaned at $21 \pm 2 \mathrm{~d}$ of age were allocated to one of three dietary treatments on the basis of BW and gender in a randomized complete block design. Each treatment was fed to eight pens with four pigs (two barrows and two gilts) per pen. The control diet was based on corn and SBM while the remaining two treatments contained either $10 \%$ SPC or FSBM (Table 4). The diets were formulated to supply SID lysine to ME ratio of $3.6 \mathrm{~g} / \mathrm{Mcal}$, and this ratio was chosen on the basis of the result of Schneider et al. (2010). All pigs had free access to feed and water during the 3-wk experiment. The SID lysine and ME contents of three soybean products and the ME content of corn were obtained according to the data obtained in Exp. 1 and Exp. 2. The ME contents of fish meal $(2,976 \mathrm{kcal} / \mathrm{kg})$, whey powder $(3,300 \mathrm{kcal} / \mathrm{kg})$, and soybean oil $(8,400 \mathrm{kcal} / \mathrm{kg})$ were obtained from NRC (1998). The SID lysine content of corn, fish meal and whey powder were determined previously using pigs surgically equipped with a T-cannula in the distal ileum by our laboratory (data not published).

The experimental pigs were housed in an environmentally controlled nursery room. The temperature was maintained between 26 and $32^{\circ} \mathrm{C}$. Each pen was $1.2 \times$ $1.5 \mathrm{~m}$ equipped with a woven mesh floor. Pigs and feeders were weighed at the beginning and end of the experiment to determine weight gain, feed intake and G:F. Fecal consistency in each pen was scored every morning using a visual scale according to the method of Song et al. (2010). The feces were ranked as follows: 1, severe diarrhea; 2 , mild diarrhea; 3 , soft feces; 4, normal feces; 5, firm but dry feces.

\section{Chemical analysis}

All soybean products were analyzed to determine dry matter (DM), crude protein $(\mathrm{CP})$, calcium $(\mathrm{Ca})$, phosphorus (P) and AA (Table 1) using the methods of the AOAC (2000). Concentrations of glycinin and $\beta$-conglycinin in all soybean products were measured using an ELISA procedure (You et al., 2008; Ma et al., 2010). The TI concentration was determined using the American Oil Chemists' Society official method Ba 12-75 (AOCS, 1998).

In Exp. 1, feed samples were collected at the start of experiment. Fecal samples were thawed, dried in an oven $\left(65^{\circ} \mathrm{C}\right)$ and ground to pass through a 1-mm sieve. Gross energy was determined using an automatic adiabatic oxygen bomb calorimeter (Parr 1281 Automatic Energy Analyzer, Moline, IL, USA).

In Exp. 2, AA in the diets and digesta were assayed using ion-exchange chromatography with an Automatic
Table 1. Analyzed nutrient composition and antigenic proteins of soybean meal (SBM), soy protein oncentrate (SPC) and fermented soybean meal (FSBM) (as-fed basis)

\begin{tabular}{|c|c|c|c|}
\hline Item & $\mathrm{SBM}^{1}$ & $\mathrm{SPC}^{2}$ & $\mathrm{FSBM}^{3}$ \\
\hline$\overline{\mathrm{DM}}(\%)$ & 88.91 & 88.85 & 89.69 \\
\hline $\mathrm{CP}(\%)$ & 46.20 & 66.30 & 56.20 \\
\hline $\mathrm{Ca}(\%)$ & 0.21 & 0.32 & 0.38 \\
\hline $\mathrm{P}(\%)$ & 0.62 & 0.80 & 0.77 \\
\hline \multicolumn{4}{|l|}{ Antigenic proteins $(\mathrm{mg} / \mathrm{g})$} \\
\hline Glycinin & 38.78 & 0.17 & 16.26 \\
\hline$\beta$-conglycinin & 116.42 & 5.54 & 24.35 \\
\hline Trypsin inhibitor (TIU/mg) & 6.85 & 0.85 & 1.15 \\
\hline \multicolumn{4}{|l|}{ Essential AA $(\%)$} \\
\hline Arginine & 3.17 & 4.35 & 3.81 \\
\hline Histidine & 1.63 & 2.45 & 1.76 \\
\hline Ileucine & 1.73 & 2.31 & 2.09 \\
\hline Leucine & 3.12 & 4.67 & 4.11 \\
\hline Lysine & 2.82 & 3.94 & 3.15 \\
\hline Methionine & 0.69 & 0.96 & 0.83 \\
\hline Phenylalanine & 2.02 & 2.46 & 2.23 \\
\hline Threonine & 2.07 & 2.73 & 2.44 \\
\hline Tryptophan & 0.61 & 0.77 & 0.74 \\
\hline Valine & 2.10 & 3.26 & 2.64 \\
\hline \multicolumn{4}{|l|}{ Nonessential AA (\%) } \\
\hline Alanine & 1.89 & 2.67 & 2.32 \\
\hline Asparagine & 4.68 & 6.17 & 5.36 \\
\hline Cystine & 0.75 & 1.00 & 0.94 \\
\hline Glutamine & 6.47 & 11.20 & 9.59 \\
\hline Glycine & 1.89 & 2.27 & 1.99 \\
\hline Proline & 2.32 & 3.97 & 3.41 \\
\hline Serine & 2.06 & 3.06 & 2.62 \\
\hline Tyrosine & 1.43 & 1.71 & 1.40 \\
\hline
\end{tabular}

${ }^{1}$ SBM (Conversional soybean meal).

${ }^{2}$ SPC (Gushen Biological Technology Group, Qingdao, China).

${ }^{3}$ FSBM (CJ Corporation, Seoul, Korea).

Amino Acid Analyzer (L-8800 Hitachi Automatic Amino Acid Analyzer, Tokyo, Japan) after hydrolyzing with 6 $\mathrm{mol} / \mathrm{L} \mathrm{HCl}$ at $110^{\circ} \mathrm{C}$ for $24 \mathrm{~h}$. Cystine was determined as cysteic acid and methinonine as methionine sulfone after preoxidation with performic acid and pre-column derivation using phenylisothiocyanate (L-8800 Hitachi Automatic Amino Acid Analyzer, Tokyo, Japan). Tryptophan was determined after hydrolyzing with $4 \mathrm{~mol} / \mathrm{L} \mathrm{NaOH}$ at $110^{\circ} \mathrm{C}$ for $22 \mathrm{~h}$ using phenylisothiocyanate (Model 76337, Agilent Technologics, Waldbronn, Germany). The chromium content in the diets and digesta was analyzed using an Atomic Absorption Spectrophotometer (Hitachi Z-5000 Automatic Absorption Spectrophotometer, Tokyo, Japan) according to Williams et al. (1962).

\section{Statistical analysis}

All data were analyzed using SAS (SAS inst. Inc., Cary, NC, USA). In Exp. 1 and Exp. 2, data were analyzed using 
Table 2. Ingredient composition of experimental diets containing soybean meal (SBM), soy protein concentrate (SPC) and fermented soybean meal (FSBM) (as-fed basis), Exp. 1

\begin{tabular}{|c|c|c|c|c|}
\hline Ingredient (\%) & Corn & $\mathrm{SBM}^{1}$ & $\mathrm{SPC}^{2}$ & $\mathrm{FSBM}^{3}$ \\
\hline Corn & 96.45 & 71.45 & 71.45 & 71.45 \\
\hline $\mathrm{SBM}(46.2 \% \mathrm{CP})$ & - & 25.00 & - & - \\
\hline SPC $(66.3 \% \mathrm{CP})$ & - & - & 25.00 & - \\
\hline FSBM $(56.2 \% \mathrm{CP})$ & - & - & - & 25.00 \\
\hline Limestone & 0.70 & 0.70 & 0.70 & 0.70 \\
\hline Dicalcium phosphate & 1.75 & 1.75 & 1.75 & 1.75 \\
\hline Salt & 0.35 & 0.35 & 0.35 & 0.35 \\
\hline Vitamin-mineral premix ${ }^{4}$ & 0.75 & 0.75 & 0.75 & 0.75 \\
\hline
\end{tabular}

${ }^{1}$ SBM (Conversional soybean meal).

${ }^{2}$ SPC (Gushen Biological Technology Group, Qingdao, China).

${ }^{3}$ FSBM (CJ Corporation, Seoul, Korea).

${ }^{4}$ Premix supplied per kg diet: vitamin A, 11,000 IU; vitamin $\mathrm{D}_{3}, 1,500 \mathrm{IU}$; vitamin E, $44.1 \mathrm{IU}$; menadione, $4.0 \mathrm{mg}$; riboflavin, $5.22 \mathrm{mg}$; pantothenic acid, $20.0 \mathrm{mg}$; niacin, $26.0 \mathrm{mg}$; vitamin $\mathrm{B}_{12}, 0.01 \mathrm{mg}$; manganese, 35.0 $\mathrm{mg}$; iron, $100.0 \mathrm{mg}$; zinc, $90.0 \mathrm{mg}$; copper, $16.5 \mathrm{mg}$; iodine, $0.30 \mathrm{mg}$; selenium, $0.30 \mathrm{mg}$.

the Proc-Mixed procedure of SAS with each replicate as the experimental unit. The statistical model for the DE, ME and SID of AA values had treatment as fixed effects, period and pig as a random effect. In Exp. 3, all data were analyzed as a randomized complete block design with pen as the experimental unit. Statistical differences among treatments were separated by Student Neuman Keul's multiple range test. When the ANOVA was significant, differences between

Table 3. Ingredient composition of experimental diets containing soybean meal (SBM), soy protein concentrate (SPC) and fermented soybean meal (FSBM) (as-fed basis), Exp. 2

\begin{tabular}{|c|c|c|c|c|}
\hline Ingredient (\%) & Nitrogen-free & $\mathrm{SBM}^{1}$ & $\mathrm{SPC}^{2}$ & $\mathrm{FSBM}^{3}$ \\
\hline Cornstarch & 73.42 & 57.65 & 65.98 & 62.77 \\
\hline Sucrose & 15.00 & 10.00 & 10.00 & 10.00 \\
\hline Solka floc & 4.00 & - & - & - \\
\hline SBM $(46.2 \% \mathrm{CP})$ & - & 27.88 & - & - \\
\hline SPC (66.3\% CP) & - & - & 19.43 & - \\
\hline FSBM $(56.2 \% \mathrm{CP})$ & - & - & - & 22.92 \\
\hline Soybean oil & 3.00 & 1.00 & 1.00 & 1.00 \\
\hline Limestone & - & 0.32 & 0.17 & 0.21 \\
\hline Dicalcium phosphate & 3.03 & 2.00 & 2.27 & 1.95 \\
\hline Salt & 0.35 & 0.35 & 0.35 & 0.35 \\
\hline Magnesium oxide & 0.10 & - & - & - \\
\hline Potassium carbonate & 0.30 & - & - & - \\
\hline Chromic oxide & 0.30 & 0.30 & 0.30 & 0.30 \\
\hline $\begin{array}{l}\text { Vitamin-mineral } \\
\text { premix }^{4}\end{array}$ & 0.50 & 0.50 & 0.50 & 0.50 \\
\hline \multicolumn{5}{|c|}{$\begin{array}{l}{ }^{1} \text { SBM (Conversional soybean meal). } \\
{ }^{2} \text { SPC (Gushen Biological Technology Group, Qingdao, China). } \\
{ }^{3} \text { FSBM (CJ Corporation, Seoul, Korea). } \\
{ }^{4} \text { Premix supplied per kg diet: vitamin A, 11,000 IU; vitamin } \mathrm{D}_{3}, 1,500 \mathrm{IU} \text {; } \\
\text { vitamin E, } 44.1 \mathrm{IU} \text {; menadione, } 4.0 \mathrm{mg} \text {; riboflavin, } 5.22 \mathrm{mg} \text {; pantothenic } \\
\text { acid, } 20.0 \mathrm{mg} \text {; niacin, } 26.0 \mathrm{mg} \text {; vitamin } \mathrm{B}_{12}, 0.01 \mathrm{mg} \text {; manganese, } 35.0 \\
\text { mg; iron, } 100.0 \mathrm{mg} \text {; zinc, } 90.0 \mathrm{mg} \text {; copper, } 16.5 \mathrm{mg} \text {; iodine, } 0.30 \mathrm{mg} \text {; } \\
\text { selenium, } 0.30 \mathrm{mg} \text {. }\end{array}$} \\
\hline
\end{tabular}

Table 4. Ingredient composition of experimental diets containing soybean meal (SBM), soy protein concentrate (SPC) and fermented soybean meal (FSBM) (as-fed basis), Exp. 3

\begin{tabular}{|c|c|c|c|}
\hline Ingredient (\%) & $\mathrm{SBM}^{1}$ & $\mathrm{SPC}^{2}$ & $\mathrm{FSBM}^{3}$ \\
\hline Corn & 57.53 & 63.05 & 60.56 \\
\hline $\operatorname{SBM}(46.2 \% \mathrm{CP})$ & 24.81 & 9.45 & 12.03 \\
\hline SPC $(66.3 \% \mathrm{CP})$ & - & 10.00 & - \\
\hline FSBM $(56.2 \% \mathrm{CP})$ & - & - & 10.00 \\
\hline Fish meal & 4.00 & 4.00 & 4.00 \\
\hline Whey powder & 8.00 & 8.00 & 8.00 \\
\hline Soybean oil & 1.70 & 1.50 & 1.50 \\
\hline Limestone & 0.59 & 0.58 & 0.54 \\
\hline Dicalcium phosphate & 1.40 & 1.39 & 1.36 \\
\hline Salt & 0.35 & 0.35 & 0.35 \\
\hline L-lysine $\mathrm{HCl}(98 \%)$ & 0.22 & 0.28 & 0.26 \\
\hline Methionine hydroxy analogue ${ }^{4}$ & 0.06 & 0.05 & 0.05 \\
\hline L-threonine $(98 \%)$ & 0.04 & 0.05 & 0.05 \\
\hline Chromic oxide ${ }^{5}$ & 0.30 & 0.30 & 0.30 \\
\hline Vitamin-mineral premix ${ }^{6}$ & 1.00 & 1.00 & 1.00 \\
\hline \multicolumn{4}{|l|}{ Calculated nutrient levels (\%) } \\
\hline $\mathrm{CP}$ & 19.40 & 19.40 & 19.40 \\
\hline SID-Lysine:ME (g/Mcal) & 3.60 & 3.60 & 3.60 \\
\hline Methionine+cystine & 0.75 & 0.75 & 0.75 \\
\hline Threonine & 0.85 & 0.85 & 0.85 \\
\hline $\mathrm{Ca}$ & 0.80 & 0.80 & 0.80 \\
\hline Total P & 0.70 & 0.70 & 0.70 \\
\hline
\end{tabular}

${ }^{1}$ SBM (Conversional soybean meal).

${ }^{2}$ SPC (Gushen Biological Technology Group, Qingdao, China).

${ }^{3}$ FSBM (CJ Corporation, Seoul, Korea).

DL-methionine hydroxy analogue (84\%) provided by Novus International, St. Louis, MO.

${ }^{5}$ The data of nutrients digestibility did not published.

${ }^{6}$ Premix supplied per kg diet: vitamin A, 11,000 IU; vitamin $\mathrm{D}_{3}, 1,500 \mathrm{IU}$; vitamin E, $44.1 \mathrm{IU}$; menadione, $4.0 \mathrm{mg}$; riboflavin, $5.22 \mathrm{mg}$; pantothenic acid, $20.0 \mathrm{mg}$; niacin, $26.0 \mathrm{mg}$; vitamin $\mathrm{B}_{12}, 0.01 \mathrm{mg}$; manganese, 35.0 $\mathrm{mg}$; iron, $100.0 \mathrm{mg}$; zinc, $90.0 \mathrm{mg}$; copper, $16.5 \mathrm{mg}$; iodine, $0.30 \mathrm{mg}$; selenium, 0.30

treatments were tested using Least Square Means (t-tests). Significance was taken at $\mathrm{p}<0.05$.

\section{RESULTS}

\section{Chemical characteristics}

The DM content in the three soybean products was similar. The concentration of all nutrients in SPC was greater than that of SBM (Table 1). The concentration of most nutrients in FSBM was also greater than SBM, except for tyrosine. Soybean products contained different concentrations of glycinin, $\beta$-conglycinin and TI with SBM having the greatest concentration $(\mathrm{SPC}<\mathrm{FSBM}<\mathrm{SBM}$ ).

\section{Energy value}

The contents of DE and ME in SPC and FSBM were greater than that of corn $(p<0.05$; Table 5$)$. The DE content 
Table 5. The DE and ME contents in diets and ingredients (as-fed basis), Exp. $1^{1}$

\begin{tabular}{|c|c|c|c|c|c|c|}
\hline Item & Corn & $\mathrm{SBM}^{2}$ & $\mathrm{SPC}^{3}$ & FSBM $^{4}$ & SEM & $\mathrm{p}$-value \\
\hline \multicolumn{7}{|l|}{ Diets } \\
\hline DE in diets $(\mathrm{kcal} / \mathrm{kg})$ & $3,223^{\mathrm{c}}$ & $3,308^{b}$ & $3,410^{\mathrm{a}}$ & $3,369^{\mathrm{ab}}$ & 24.3 & 0.002 \\
\hline ME in diets $(\mathrm{kcal} / \mathrm{kg})$ & $3,172^{\mathrm{c}}$ & $3,201^{\mathrm{bc}}$ & $3,297^{\mathrm{a}}$ & $3,265^{\mathrm{ab}}$ & 24.8 & 0.025 \\
\hline \multicolumn{7}{|l|}{ Ingredients } \\
\hline DE in ingredients $(\mathrm{kcal} / \mathrm{kg})$ & $3,342^{\mathrm{c}}$ & $3,677^{\mathrm{b}}$ & $4,086^{\mathrm{a}}$ & $3,924^{\mathrm{ab}}$ & 82.8 & 0.004 \\
\hline ME in ingredients $(\mathrm{kcal} / \mathrm{kg})$ & $3,290^{\mathrm{c}}$ & $3,399^{\mathrm{bc}}$ & $3,784^{\mathrm{a}}$ & $3,655^{\mathrm{ab}}$ & 84.4 & 0.019 \\
\hline
\end{tabular}

${ }^{1}$ Data are the means of four pigs (initial BW of $14.2 \pm 1.4 \mathrm{~kg}$ ) used in a $4 \times 4$ Latin square design.

${ }^{2}$ SBM (Conversional soybean meal). ${ }^{3}$ SPC (Gushen Biological Technology Group, Qingdao, China). ${ }^{4}$ FSBM (CJ Corporation, Seoul, Korea).

${ }^{a, b, c}$ Means in the same row with different superscripts are significantly different $(\mathrm{p}<0.05)$.

for SBM was greater than that of corn $(p<0.05)$, but their $\mathrm{ME}$ contents did not differ. The DE and ME contents of SPC were greater than that of SBM $(p<0.05)$, but not different from FSBM.

\section{SID of AA}

The SID of CP and AA in the various soybean products are summarized in Table 6. The SID of CP in SPC $(89.25 \%$ was greater than in SBM $(84.03 \%(\mathrm{p}<0.05)$, while the SID of CP in FSBM $(87.68 \%)$ was intermediate to that of the other two soybean products. The SID of most AA in SPC were greater than in SBM $(\mathrm{p}<0.05)$, except for methionine, phenylalanine, tryptophan, valine and proline. For essential AA, the SID of histidine, isoleucine, leucine, lysine and threonine in FSBM were greater than in SBM $(p<0.05)$. For nonessential AA, the SID of alanine and glycine in FSBM were greater than in SBM $(\mathrm{p}<0.05)$. The SID of most AA in FSBM was not different from SPC except for the SID of arginine, glutamine and serine, which was greater in SPC than in FSBM $(\mathrm{p}<0.05)$.

\section{Pig performance}

The pigs fed SPC or FSBM diets had greater weight gain than pigs fed SBM diet although the SID lysine to ME

Table 6. SID of CP and AA in soybean meal (SBM), soy protein concentrate (SPC) and fermented soybean meal (FSBM), Exp. $2^{1}$

\begin{tabular}{|c|c|c|c|c|c|}
\hline Item & $\mathrm{SBM}^{2}$ & $\mathrm{SPC}^{3}$ & $\mathrm{FSBM}^{4}$ & SEM & p-value \\
\hline$\overline{\mathrm{CP}(\%)}$ & $84.03^{b}$ & $89.25^{\mathrm{a}}$ & $87.68^{\mathrm{ab}}$ & 1.55 & 0.038 \\
\hline \multicolumn{6}{|l|}{ Essential AA (\%) } \\
\hline Arginine & $88.37^{b}$ & $93.84^{\mathrm{a}}$ & $89.47^{b}$ & 1.83 & 0.038 \\
\hline Histidine & $84.12^{b}$ & $90.02^{\mathrm{a}}$ & $88.87^{\mathrm{a}}$ & 1.39 & 0.012 \\
\hline Ileucine & $84.92^{b}$ & $91.37^{\mathrm{a}}$ & $88.97^{\mathrm{a}}$ & 1.15 & 0.007 \\
\hline Leucine & $86.05^{\mathrm{b}}$ & $92.70^{\mathrm{a}}$ & $91.49^{\mathrm{a}}$ & 1.71 & 0.043 \\
\hline Lysine & $85.02^{b}$ & $90.20^{\mathrm{a}}$ & $89.96^{\mathrm{a}}$ & 1.62 & 0.013 \\
\hline Methionine & 87.27 & 89.90 & 88.92 & 1.93 & 0.093 \\
\hline Phenylalanine & 86.63 & 89.19 & 88.49 & 1.88 & 0.170 \\
\hline Threonine & $80.47^{b}$ & $87.32^{\mathrm{a}}$ & $85.71^{a}$ & 1.66 & 0.015 \\
\hline Tryptophan & 86.65 & 90.19 & 87.37 & 2.16 & 0.180 \\
\hline Valine & 87.60 & 91.60 & 88.52 & 1.62 & 0.082 \\
\hline Mean & $85.71^{b}$ & $90.63^{\mathrm{a}}$ & $88.78^{\mathrm{ab}}$ & 1.53 & 0.012 \\
\hline \multicolumn{6}{|c|}{ Nonessential AA (\%) } \\
\hline Alanine & $79.67^{b}$ & $89.58^{\mathrm{a}}$ & $87.94^{\mathrm{a}}$ & 2.31 & 0.019 \\
\hline Asparagine & $85.07^{\mathrm{b}}$ & $90.16^{\mathrm{a}}$ & $86.84^{\mathrm{ab}}$ & 1.30 & 0.040 \\
\hline Cystine & $82.12^{b}$ & $86.57^{\mathrm{a}}$ & $85.31^{\mathrm{ab}}$ & 1.26 & 0.032 \\
\hline Glutamine & $83.34^{\mathrm{b}}$ & $91.54^{\mathrm{a}}$ & $87.97^{b}$ & 2.22 & 0.002 \\
\hline Glycine & $84.28^{\mathrm{b}}$ & $88.81^{\mathrm{a}}$ & $87.70^{\mathrm{a}}$ & 1.50 & 0.027 \\
\hline Proline & 120.04 & 124.39 & 128.58 & 17.92 & 0.402 \\
\hline Serine & $82.81^{b}$ & $89.07^{\mathrm{a}}$ & $84.06^{\mathrm{b}}$ & 2.14 & 0.016 \\
\hline Tyrosine & $86.93^{b}$ & $90.89^{\mathrm{a}}$ & $87.98^{\mathrm{ab}}$ & 1.01 & 0.021 \\
\hline Mean & $88.03^{\mathrm{b}}$ & $93.88^{\mathrm{a}}$ & $92.17^{\mathrm{ab}}$ & 1.17 & 0.011 \\
\hline All AA & $86.74^{\mathrm{b}}$ & $92.07^{\mathrm{a}}$ & $90.29^{\mathrm{ab}}$ & 1.73 & 0.028 \\
\hline
\end{tabular}

${ }^{1}$ Data are the means of four pigs (initial BW of $18.2 \pm 1.5 \mathrm{~kg}$ ) used in a $4 \times 4$ Latin square design.

${ }^{2}$ SBM (Conversional soybean meal). ${ }^{3}$ SPC (Gushen Biological Technology Group, Qingdao, China). ${ }^{4}$ FSBM (CJ Corporation, Seoul, Korea)

${ }^{a, b, c}$ Means in the same row with different superscripts are significantly different $(p<0.05)$. 
Table 7. Effects of same SID lysine:ME ratio (3.6 g/Mcal) diets containing soybean meal (SBM), soy protein concentrate (SPC) and fermented soybean meal (FSBM) on the performance of early-weaned piglets, Exp. $3^{1}$

\begin{tabular}{|c|c|c|c|c|c|}
\hline Item & $\mathrm{SBM}^{2}$ & $\mathrm{SPC}^{3}$ & $\mathrm{FSBM}^{4}$ & SEM & p-value \\
\hline \multicolumn{6}{|l|}{ Performance } \\
\hline Weight gain $(\mathrm{g} / \mathrm{d})$ & $295^{\mathrm{b}}$ & $352^{\mathrm{a}}$ & $345^{\mathrm{a}}$ & 11.31 & 0.009 \\
\hline Feed intake (g/d) & 421 & 436 & 451 & 8.84 & 0.083 \\
\hline $\mathrm{G}: \mathrm{F}$ & $0.70^{\mathrm{b}}$ & $0.81^{\mathrm{a}}$ & $0.76^{\mathrm{a}}$ & 0.02 & 0.022 \\
\hline \multicolumn{6}{|l|}{ Fecal score } \\
\hline $1-7 d$ & $2.13^{\mathrm{b}}$ & $2.89^{\mathrm{a}}$ & $2.78^{\mathrm{a}}$ & 0.17 & 0.014 \\
\hline $7-14 \mathrm{~d}$ & $2.21^{\mathrm{b}}$ & $2.92^{\mathrm{a}}$ & $2.86^{\mathrm{a}}$ & 0.21 & 0.033 \\
\hline $14-21 d$ & $2.48^{\mathrm{b}}$ & $2.93^{\mathrm{a}}$ & $2.88^{\mathrm{ab}}$ & 0.13 & 0.021 \\
\hline $1-21 d$ & $2.28^{\mathrm{b}}$ & $2.91^{\mathrm{a}}$ & $2.84^{\mathrm{a}}$ & 0.17 & 0.019 \\
\hline
\end{tabular}

${ }^{1}$ A total of 96 pigs (initial BW of $5.6 \pm 0.9 \mathrm{~kg}$ and $21 \pm 2 \mathrm{~d}$ of age) were allotted to provide four pigs per pen and eight pens per treatment.

${ }^{2}$ SBM (Conversional soybean meal). ${ }^{3}$ SPC (Gushen Biological Technology Group, Qingdao, China). ${ }^{4}$ FSBM (CJ Corporation, Seoul, Korea).

${ }^{\mathrm{a}, \mathrm{b}}$ Means in the same row with different superscripts are significantly different $(\mathrm{p}<0.05)$.

ratio was consistent $(\mathrm{p}<0.05)$, however no differences were detected in weight gain between pigs fed SPC or FSBM diets. Pigs fed the SBM diet had lower G:F than pigs fed SPC or FSBM diets $(\mathrm{p}<0.05)$. From d 1 through 7 , as well as from $\mathrm{d} 8$ through 14 and in the overall experimental period, the fecal scores of pigs fed SPC or FSBM diets were significantly better than pigs fed the SBM diet $(\mathrm{p}<0.05)$.

\section{DISCUSSION}

The concentrations of $\mathrm{CP}$ and AA in SBM were similar to the concentrations reported by NRC (1998) and Woodworth et al. (2001). The concentrations of CP and AA in SPC and FSBM were also similar to the results from Urbaityte et al. (2009) and Cervantes-Pahm and Stein (2010). In current study, SPC and FSBM contained more CP, $\mathrm{AA}, \mathrm{Ca}, \mathrm{P}$ and less glycinin, $\beta$-conglycinin and TI than that of SBM, the finding was consistent with the results of Chen et al. (2010), who found that FSBM and SPC contained higher protein, most of essential AA, and lower soybean antigen proteins than untreated raw SBM. Fermentation of SBM can remove anti-nutritional factors and modify AA profiles by microbial AA synthesis and breakdown (Hong et al., 2004). Additionally, the processing of SPC similarly could increase the nutrient levels by removing most of the water-soluble and non-protein constituents, and it contains relatively small amounts of anti-nutritional factors (Sissons and Smith, 1976; Kilshaw and Sissons, 1979). This indicates that the SPC and FSBM used in current study were good quality products that the nutrients content were increased and the anti-nutritional factors content were mostly decreased during both concentration and fermentation.

From the results in Exp. 1, we can see that the DE $(3,342 \mathrm{kcal} / \mathrm{kg})$ and $\mathrm{ME}(3,290 \mathrm{kcal} / \mathrm{kg})$ contents of corn measured in this experiment are slightly greater than the values reported by Adeola and Bajjalieh (1997). The DE
$(3,677 \mathrm{kcal} / \mathrm{kg})$ and $\mathrm{ME}(3,399 \mathrm{kcal} / \mathrm{kg})$ contents of SBM are close to previous data (Woodworth et al., 2001; Goebel and Stein, 2011). The DE (4,086 kcal/kg) and $\operatorname{ME~}(3,784$ $\mathrm{kcal} / \mathrm{kg}$ ) contents of SPC are similar to the values published by NRC (1998). Additionally, no significant difference existed in ME between corn and SBM, in agreement with the data reported by Baker and Stein (2009). Therefore, the values obtained in the present study for soybean products appear to be reasonable and can be used to formulate diets in pig production as the information about $\mathrm{DE}$ and $\mathrm{ME}$ contents in FSBM are limited.

From the DE and ME results we observed that although the statistical values were not significant, FSBM had greater $\mathrm{DE}(6.7 \%)$ and $\mathrm{ME}(7.5 \%)$ values than SBM, whereas DE and ME contents of SPC were significantly higher than SBM $(p<0.05)$, which suggests that the energy utilization of SPC and FSBM were increased during their processing. The increased DE and ME contents in SPC and FSBM may be attributed to the composition changes after concentration and fermentation. The TI, as well as oligosaccharides like raffinose and stachyose which are difficult to digest in SBM was removed during fungal and bacterial fermentation by protease and glucoamylase causing hydrolysis (Kim, 2005). Chen et al. (2010) also suggested that some oligosaccharides such as stachyose and raffinose were lower in SPC and FSBM than SBM. So the more digestible composition in SPC and FSBM may improve their energy utilization.

The results for the SID of AA in SBM were consistent with the results of Woodworth et al. (2001). The results for the SID of AA in SPC were less than NRC (1998), but similar to Urbaityte et al. (2009). Friesen et al. (1993b) suggested that moist extrusion of less-refined soy products (soy flakes, soy flour, and soybean meal) can produce a superior soy product for inclusion in starter pig diets compared with dry extrusion of soybean meal, because it is greater control in preventing overheating, which can result 
in lower product digestibility. Therefore, the difference of the results might be due to the different processing method used for concentration.

The results for the SID of AA in FSBM were higher than the report of Urbaityte et al. (2009) and CervantesPahm and Stein (2010). In the study of Cervantes-Pahm and Stein (2010), the batch of FSBM that was used may have been overheated, and the concentration of glycinin and $\beta$-conglycinin in the FSBM was not different from the concentrations in SBM, which may contribute to the lack of a difference in the digestibility of AA between FSBM and SBM. In the current study, Bacillus subtilis live strains were used to process FSBM, whereas, in study of Urbaityte et al. (2009), Lactobacillus subtilis were used, the different efficiency Bacillus subtilis between Lactobacillus subtilis during fermentation may cause different effect on AA digestibility. In current study, the SID of some essential AA such as histidine, isoleucine, leucine, lysine and threonine was improved for the pigs fed FSBM diet compared with the pigs fed SBM diet, which is similar with Yang et al. (2007) who reported that with the exception of Arg, Ile, Lys, Gly, and Pro, there are no differences in the SID of AA between FSBM and SBM. Min et al. (2004) also suggested that pigs fed increasing concentrations of FSBM had increased weight gain and improved AID of histidine, lysine and threonine. From these results we speculate that the difference results for SID of AA might be due to the different manipulation or/and the microorganisms used during fermentation, the increased digestibility of AA in FSBM may be only observed in some essential AA rather than offering improvement of all AA.

Furthermore, the increased number of small peptides may also contribute to the higher SID of some essential AA in FSBM than SBM. Hong et al. (2004) suggested that during fermentation, large proteins SBM could be hydrolyzed into AA, and as a result, fermented soybeans do not contain large peptides $(>60 \mathrm{kD})$. The increased number of smaller size peptides $(<20 \mathrm{kD})$ in fermented soybeans is due to partial digestion of large proteins by protease secreted by microorganisms, a mechanism beneficial for protein utilization (Sarkar et al., 1995). Small peptides have been thought to be absorbed easier than large proteins. Newly weaned pigs have a considerable capacity to absorb peptides in the small intestine (Gilbert et al., 2008).

In Exp. 3, pigs fed diets containing SPC and FSBM had greater weight gain and improved G:F compared with pigs fed the SBM diet. Because the SID lysine to ME ratio and other nutrients content were kept consistent among diets, the only different thing was the different levels of SBM. In current study, the SPC and FSBM diets contained lower levels of SBM $(9.45 \%$ and $12.03 \%$, respectively) than the SBM $(24.81 \%)$ diet. In addition, our results demonstrated that SBM had greater concentration of glycinin, $\beta$-conglycinin and TI than SPC and FSBM. The exist of them may damage the intestinal morphology and cause allergen reaction, diarrhea of weaning pigs (Dunsoford et al., 1989; Li et al., 1991; Sun et al., 2008). Further, cooked and fermented soya beans could be beneficial in the control of diarrhea in ETEC-challenged weaned piglets and significantly improve weight gain and feed intake (Kiers et al., 2003). This is consistent with our results that the pigs fed the SPC and FSBM diets had a lower incidence of diarrhea than the pigs fed diet with SBM.

Our findings suggest that SPC showed a higher ME content and SID of AA than the SBM. SID of some essential AA in FSBM was higher than SBM and was similar with SPC. But the lower antigenic proteins and antinutritional factors content in SPC and FSBM may be the main factors that affecting the performance of early-weaned piglets rather than the increased ME content and SID of AA.

\section{ACKNOWLEDGEMENTS}

The financial support received from the National Natural Science Foundation of China (No.31072040), the State Key Laboratory of Animal Nutrition of China (No. 2004DA125184F1211), Ministry of Science and Technology of China (No. NYHYZX07-034), and the CJ Corporation, Seoul, Korea.

\section{REFERENCES}

Adeola, O. and N. L. Bajjalieh. 1997. Energy concentration of high-oil corn varieties for pigs. J. Anim. Sci. 75:430-436.

AOAC. 2000. Official methods of analysis, 17th ed. Association of Official Analytical Chemists, Arlington. VA, USA.

AOCS. 1998. Official methods and recommended practices of the AOCS. 5th ed. Am. Oil Chem. Soc., Champaign, IL, USA.

Baker, K. M. and H. H. Stein. 2009. Amino acid digestibility and concentration of digestible and metabolizable energy in soybean meal produced from high protein or low oligosaccharide varieties of soybeans and fed to growing pigs. J. Anim. Sci. 87:2282-2290.

Cervantes-Pahm, S. K. and H. H. Stein. 2010. Ileal digestibility of amino acids in conventional, fermented, and enzyme-treated soybean meal and in soy protein isolate, fish meal, and casein fed to weanling pig. J. Anim. Sci. 88:2674-2683.

Chen, C. C., Y. C. Shih, P. W. S. Chiou and B. Yu. 2010. Evaluating nutritional quality of single stage- and two stagefermented soybean meal. Asian Australas. J. Anim. Sci. 23:598-606.

Cho, J. H., B. J. Min, Y. J. Chen, J. S. Yoo, Q. Wang, J. D. Kim and I. H. Kim. 2007. Evaluation of FSP (fermented soy protein) to replace soybean meal in weaned pigs: Growth performance, blood urea nitrogen and total protein concentrations in serum and nutrient digestibility. Asian Australas. J. Anim. Sci. 20:1874-1879. 
Cromwell, G. L. 2000. Utilization of soy products in swine diets. In: Soy in Animal Nutrition (Ed. J. K. Drackley). Fed. Anim. Sci. Soc., Savoy, IL, USA, pp. 258-282.

Csaky, I. and S. Fekete. 2004. Soybean: Feed quality and safety. Part 2: Pathology of soybean feeding in animals: A review. Acta Vet. Hung. 52:315-326.

Dunsoford, B. R., D. A. Knabe and W. E. Hacnsly. 1989. Effect of dietary soybean meal on the microscopic anatomy of the small intestine in the early-weaned pig. J. Anim. Sci. 72:1855-1863.

Feng, J., X. Liu, Z. R. Xu, Y. P. Lu and Y. Y. Li. 2007. Effect of fermented soybean meal on intestinal morphology and digestive enzyme activities in weaned piglets. Dig. Dis. Sci. 52:1845-1850.

Friesen, K. G., J. L. Nelssen, R. D. Goodband, K. C. Behnke and L. J. Kats. 1993b. The effect of moist extrusion of soy products on growth performance and nutrient utilization in the earlyweaned pig. J. Anim. Sci. 71:2099-2109.

Gilbert, E. R., E. A. Wong and K. E. Webb Jr. 2008. Peptide absorption and utilization: Implications for animal nutrition and health. J. Anim. Sci. 86:2135-2155.

Goebel, K. P. and H. H. Stein. 2011. Phosphorus digestibility and energy concentration of enzyme-treated and conventional soybean meal fed to weanling pigs. J. Anim. Sci. 89:764-772.

Hamerstrand, G. E., L. T. Black and J. D. Glover. 1981. Trypsin inhibitors in soy products: Modification of the standard analytical procedure. Cereal Chem. 58:42-45.

Hao, Y., D. F. Li, X. L. Piao and X. S. Piao. 2010. Forsythia suspensa extract alleviates hypersensitivity induced by soybean $\beta$-conglycinin in weaned piglets. J. Ethnopharmacol. 128:412-418.

Hong, K. J., C. H. Lee and S. W. Kim. 2004. Aspergillus oryzae GB-107 fermentation improves nutritional quality of food soybeans and feed soybean meals. J. Med. Food 7:430-435.

Jones, C. K., J. M. DeRouchey, J. L. Nelssen, M. D. Tokach, S. S. Dritz and R. D. Goodband. 2010. Effects of fermented soybean meal and specialty animal protein sources on nursery pig performance. J. Anim. Sci. 88:1725-1732.

Kiers, J. L., J. C. Meijer, M. J. R. Nout, F. M. Rombouts, M. J. A. Nabuurs and J. van der Meulen. 2003. Effect of fermented soya beans on diarrhoea and feed efficiency in weaned piglets. J. Appl. Microbiol. 95:545-552.

Kilshaw, P. I. and J. W. Sissons. 1979. Gastrointestinal allergy to soybean protein in preruminant calves. Allergenic constituents of soybean products. Res. Vet. Sci. 27:366-371.

Kim, S. W., R. D. Mateo and F. Ji. 2005. Fermented soybean meal as a protein source in nursery diets replacing dried skim milk. J. Anim. Sci. 83 (Supp.1):116 (Abstract).

Kim, Y. G. 2005. Effects of feeding fermented soy protein on growth performance, nutrients digestibility, intestinal morphology and immune response in weaned pigs. Ph. D. Thesis, Kangwon National University, Korea.

Kwon, D. Y., W. James, III Daily, H. J. Kim and S. Park. 2010. Anti-diabetic effects of fermented soybean products on type 2 diabetes. Nutr. Res. 30:1-13.

Lenehan, N. A., J. M. DeRouchey, R. D. Goodband, M. D. Tokach, S. S. Dritz, J. L. Nelssen, C. N. Groesbeck and K. R. Lawrence. 2007. Evaluation of soy protein concentrates in nursery pig diets. J. Anim. Sci. 85:3013-3021.
Li, D. F., J. L. Nelssen, P. G. Reddy, F. Blecha, J. D. Hancock, G. L. Allee, R. D. Goodband and R. D. Klemm. 1990. Transient hypersensitivity to soybean meal in the early-weaned pig. J. Anim. Sci. 68:1790-1799.

Li, D. F., J. L. Nelssen, P. G. Reddy, F. Blecha, R. D. Klemm, D. W. Giesting, J. D. Hancock, G. L. Allee and R. D. Goodband. 1991. Measuring suitability of soybean products for earlyweaned pigs with immunological criteria. J. Anim. Sci. 69:3299-3307.

Ma, X., P. Sun, P. L. He, P. F. Han, J. J. Wang, S. Y. Qiao and D. F. Li. 2010. Development of monoclonal antibodies and a competitive ELISA detection method for glycinin, an allergen in soybean. Food Chem. 121:546-551.

Min, B. J., J. W. Hong, O. S. Kwon, W. B. Lee, Y. C. Kim, I. H. Kim, W. T. Cho and J. H. Kim. 2004. The effect of feeding processed soy protein on the growth performance and apparent ileal digestibility in weanling pigs. Asian Australas. J. Anim. Sci. 17:1271-1276.

NRC. 1998. Nutrient requirements of swine, 10th ed. National Academy Press, Washington, DC, USA.

Petersen, G. I. and H. H. Stein. 2006. Novel procedure for estimating endogenous losses and measuring apparent and true digestibility of phosphorus by growing pigs. J. Anim. Sci. 84:2126-2132.

Sarkar, P. K. and J. P. Tamang. 1995. Changes in the microbial profile and proximate composition during natural and controlled fermentations of soybeans to produce kinema. Food Chem. 12:317-325.

SAS. 1999. SAS user's guide: Statistics (Version 8.01). SAS Inst. Inc., Cary, NC, USA.

Schneider, J. D., M. D. Tokach, S. S. Dritz, J. L. Nelssen, J. M. DeRouchey and R. D. Goodband. 2010. Determining the effect of lysine:calorie ratio on growth performance of ten- to twenty-kilogram of body weight nursery pigs of two different genotypes. J. Anim. Sci. 88:137-146.

Sissons, J. W. and R. H. Smith. 1976. The effect of different diets including those containing soybean products on digesta movement and water and nitrogen absorption in the small intestine of the pre-ruminant calf. Br. J. Nutr. 36:421-438.

Sohn, K. S., C. V. Maxwell, D. S. Buchanan and L. L. Southern. 1994a. Improved soybean protein sources for early-weaned pigs: I. Effects on performance and total tract amino acid digestibility. J. Anim. Sci. 72:622-630.

Song, Y. S., V. G. Pérez, J. E. Pettigrew, C. Martinez-Villaluenga and E. Gonzalez de Mejia. 2010. Fermentation of soybean meal and its inclusion in diets for newly weaned pigs reduced diarrhea and measures of immunoreactivity in the plasma. Anim. Feed Sci. Technol. 159:41-49.

Stein, H. H., C. F. Shipley and R. A. Easter. 1998. Technical note: A technique for inserting a T-cannula into the distal ileum of pregnant sows. J. Anim. Sci. 76:1433-1436.

Sun, P., D. F. Li, Z. J. Li, B. Dong and F. L. Wang. 2008. Effects of glycinin on IgE-mediated increase of mast cell numbers and histamine release in the small intestine. J. Nutr. Biochem. 19:627-633.

Urbaityte, R., R., Mosenthin, M. Eklund, H. Piepho, N. Sauer and M. Rademacher. 2009. Standardised ileal crude protein and amino acid digestibilities in protein supplements for piglets. 
Arch. Anim. Nutr. 63:356-378.

Williams, C. H., D. J. David and O. Iismaa. 1962. The determination of chromic oxide in faeces sample y atomic absorption spectrophotometry. J. Agric. Sci. 59:381-385.

Woodworth, J. C., M. D. Tokach, R. D. Goodband, J. L. Nelssen, P. R. O'Quinn, D. A. Knabe and N. W. Said. 2001. Apparent ileal digestibility of amino acids and the digestible and metabolizable energy content of dry extruded-expelled soybean meal and its effects on growth performance of pigs. J. Anim. Sci. 79:1280-1287.
Yang, Y. X., Y. G. Kim, J. D. Lohakare, J. H. Yun, J. K. Lee, M. S. Kwon, J. I. Park, J. Y. Choi and B. J. Chae. 2007. Comparative efficacy of different soy protein sources on growth performance, nutrient digestibility, and intestinal morphology in weaned pigs. Asian Australas. J. Anim. Sci. 20:775-783.

You, J. M., D. F. Li, S. Y. Qiao, Z. R. Wang, P. L. He, D. Y. Ou and B. Dong. 2008. Development of a monoclonal antibody-based competitive ELISA for detection of $\beta$-conglycinin, an allergen from soybean. Food Chem. 106:352-360. 